NBER WORKING PAPER SERIES

\title{
WHY ARE AMERICAN WORKERS GETTING POORER? CHINA, TRADE AND OFFSHORING
}

\author{
Avraham Ebenstein \\ Ann Harrison \\ Margaret McMillan \\ Working Paper 21027 \\ http://www.nber.org/papers/w21027 \\ NATIONAL BUREAU OF ECONOMIC RESEARCH \\ 1050 Massachusetts Avenue \\ Cambridge, MA 02138 \\ March 2015
}

Special thanks to David Autor, Robert Feenstra, Wayne Gray, and Lawrence Edwards for providing data critical to our analysis. Excellent research assistance was provided by Susan Schwartz. We also thank seminar participants at the University of Paris in preparation for the book, "The Factory - Free Economy", edited by Lionel Fontagne and Ann Harrison, as well as seminar participants at the World Bank. The views expressed herein are those of the authors and do not necessarily reflect the views of the National Bureau of Economic Research.

NBER working papers are circulated for discussion and comment purposes. They have not been peerreviewed or been subject to the review by the NBER Board of Directors that accompanies official NBER publications.

(C) 2015 by Avraham Ebenstein, Ann Harrison, and Margaret McMillan. All rights reserved. Short sections of text, not to exceed two paragraphs, may be quoted without explicit permission provided that full credit, including (C) notice, is given to the source. 
Why are American Workers getting Poorer? China, Trade and Offshoring

Avraham Ebenstein, Ann Harrison, and Margaret McMillan

NBER Working Paper No. 21027

March 2015

JEL No. F16,F66

\begin{abstract}
$\underline{\text { ABSTRACT }}$
We suggest that the impact of globalization on wages has been missed because its effects must be captured by analyzing occupational exposure to globalization. In this paper, we extend our previous work to include recent years (2003-2008), a period of increasing import penetration, China's entry into the WTO, and growing US multinational employment abroad. We find significant effects of globalization, with offshoring to low wage countries and imports both associated with wage declines for US workers. We present evidence that globalization has led to the reallocation of workers away from high wage manufacturing jobs into other sectors and other occupations, with large declines in wages among workers who switch, explaining the large differences between industry and occupational analyses. While other research has focused primarily on China's trade, we find that offshoring to China has also contributed to wage declines among US workers. However, the role of trade is quantitatively much more important. We also explore the impact of trade and offshoring on labor force participation rates. While offshoring to China has a negative impact on US labor force participation, other factors such as increasing computer use and substitution of capital for labor are significantly more important determinants of US employment rates across occupations.
\end{abstract}

Avraham Ebenstein

Department of Economics

Hebrew University of Jerusalem

Mount Scopus Campus, \#4208

Jerusalem, Israel 91905

ebenstein@mscc.huji.ac.il

Ann Harrison

Management Department

The Wharton School

University of Pennsylvania

2016 Steinberg Hall-Dietrich Hall

3620 Locust Walk

Philadelphia, PA 19104-6370

and NBER

annh@wharton.upenn.edu
Margaret McMillan

Tufts University

Department of Economics

114a Braker Hall

Medford, MA 02155

and International Food Policy Research Institute

and also NBER

margaret.mcmillan@tufts.edu 


\section{Introduction}

Between 1983 and 2008, the United States economy experienced a doubling of imports of manufactured goods, and US multinational corporations tripled their employment in low income countries. Over this same period, domestic American manufacturing employment declined from 22 million to 16 million (CPS). Since the "great recession" of 2008, US manufacturing has declined precipitously, with nearly 2 million additional jobs lost. Today, the US employment recovery remains anemic, and millions of Americans of working age are either unemployed or out of the labor force entirely. Many blame these trends on globalization, and in particular on China.

Following China's accession to the World Trade Organization (WTO) in 2001, Chinese imports to the US surged. Chinese imports currently represent over 8 percent of total imports and nearly six hundred thousand Chinese workers were employed at US multinational affiliates by 2008. These parallel developments led some critics of globalization to conclude that "good" manufacturing jobs had been shipped overseas, and America's pre-eminence in the world economy has been usurped by China. But defenders of globalization respond that the role of trade and offshoring in these trends is exaggerated. They argue that empirical support for a direct role of foreign competition in explaining the decline in US manufacturing is limited, in spite of popular opinion blaming globalization and China in particular.

One possible explanation for the lack of evidence regarding the impact of trade on American workers is that most research has focused on analysis of workers in affected industries. In the standard approach, the wage effects of import competition on wages are identified by exploiting variation in the prices (or quantities) of imported goods across different manufacturing industries and examine their impact within manufacturing. Examples include Feenstra and 
Hanson (1999), Bernard, Jensen, and Schott (2006), Autor, Dorn, and Hanson (2013), and others. However, these papers generally ignore a key marker for exposure to overseas competition, which is whether a worker's occupation can be performed more cheaply and reliably in China. Relying on analysis at the industry level may also fail to account for structural change that occurs in response to trade. Insofar as globalization affects the US labor market by pushing workers out of manufacturing and into services, a better measure of globalization's impact is found by focusing on occupational exposure to globalization. This is because workers can more easily switch industries than occupations (Kambourov and Manovskii 2009a and 2009b), and so the wage declines will be felt by workers who are forced to leave manufacturing or their occupation entirely.

In Ebenstein, Harrison, McMillan, and Phillips (2014), we present evidence that an occupation-based analysis is more effective at uncovering the impact on worker wages of global competition. We find significant wage declines for American workers exposed to globalization, especially among workers performing tasks that are routine, and can presumably be performed offshore. In this paper, we extend this work, and improve upon it in several ways. Due to data limitations, Ebenstein et al. (2014) focused on the period between 1983 and 2002. ${ }^{1}$ In this paper, we include the effects of globalization observed up to 2008, which allows us to include a period characterized by rapid increases in offshoring, especially to China following its accession to the WTO at the end of 2001.

In this paper we also focus greater attention on the differences between offshoring and imports. Most recent papers analyzing the impact of trade on labor outcomes (e.g. Autor, Dorn, and Hanson 2013 or Pierce and Schott 2012) focus on trade in goods. However, trade in tasks, or

\footnotetext{
${ }^{1}$ The updated analysis was made possible by recently- released trade and offshoring data, as well as IPUMSMinnesota, which provided concordances necessary to generate industry and occupation codes consistent over time, including the switch between 2002 and 2003 from SIC to NAICS.
} 
offshoring, has the ability to affect a much wider class of workers. As we will demonstrate, while imports are often found in low value added sectors (e.g. toys), offshore employment is most common in high value added sectors, such as motor vehicles and electronics, where companies would not want to share their intellectual property with a foreign firm. These industries have historically had higher rates of unionization, and higher US wages. This new trend is potentially much more threatening to American workers by reducing their bargaining leverage. Insofar as the threat to move a factory overseas to China is credible, globalization can generate downward pressure on wages, and affect even those workers whose jobs are not sent overseas. If the wages prevailing in an occupation become sufficiently low relative to historical standards, many older workers may begin to exit the labor force entirely.

A second contribution of this paper is to disaggregate the impact of geographically distinct sources of offshore employment changes on domestic US wages. In particular, we measure the impact of offshore employment by US multinationals in China, Mexico, India, and other low income locations. We also compare their impact on domestic US wages with offshore employment growth in high income locations. We concentrate our analysis on China, and compare the effects of import competition from China and offshore employment in China on US worker wages.

Consistent with our earlier work, we find that offshoring to low wage countries is associated with wage declines for US workers, and the workers most affected are those performing routine tasks. Our results indicate that a ten percentage point increase in occupational exposure to import competition is associated with a 2.7 percent decline in real wages for workers who perform routine tasks. ${ }^{2}$ We also find substantial wage effects of offshoring to low wage

\footnotetext{
${ }^{2}$ This finding is consistent with recent work highlighting the differential impact of offshoring by worker skill type. Hummels, Jøgensen, Munch and Xiang (2011) use matched worker and firm data from Denmark and find that
} 
countries: a ten percent increase in occupation-specific exposure to overseas employment in low wage countries is associated with a 0.27 percent decline in real wages for workers performing routine tasks for our entire sample, and nearly a 1 percent decline for 2000-2008. The wages of workers without higher education and older workers are disproportionately affected by offshoring activities, as the point estimates are larger for these groups of workers. If instead we measure exposure to globalization at the industry level, we find no significant effects on US worker wages.

The downward pressure from trade and offshoring on US wages using occupational (but not industry-level) measures of globalization explains the puzzling results reported in Autor, Dorn, and Hanson (2013). They find a positive, but insignificant impact of import competition on local wages, leading them to conclude that "manufacturing plants react to import competition by accelerating technological and organizational innovations that increase productivity and may raise wages". Our research suggests that occupational exposure to globalization puts significant downward pressure on wages because such a measure captures the movement of workers out of manufacturing and into lower wage services.

We explicitly test the importance of this mechanism to confirm the stark differences between occupational versus industry measures of globalization. Using a subset of the CPS data where we are able to follow the same worker over time, we measure what happens to worker wages when they switch industries or occupations. Since our original exercise was motivated by the possibility that globalization has affected US workers by forcing them out of manufacturing ${ }^{3}$,

offshoring raises skilled worker wages but lowers unskilled worker wages, while exporting raises the wages of all types of workers.

${ }^{3}$ Our results corroborate results on employment declines within manufacturing by Harrison and McMillan (2011) who use firm-level data on multinational manufacturing firms, but stand in contrast to Desai, Foley, and Hines (2009). Desai, Foley, and Hines do not distinguish between high wage and low wage affiliate employment and find that offshoring is unambiguously positive for US employment. 
we directly examine the wage impact of switching within manufacturing, switching from manufacturing, and finally, both switching out of manufacturing and switching occupations. We find evidence that while the wage impacts of switches within manufacturing are mild, leaving manufacturing for services is associated with an appreciable loss in wages, and larger losses still for workers who are forced to switch occupation upon leaving manufacturing. This highlights the importance of examining the impact of globalization by looking beyond workers only employed directly in manufacturing.

We then turn to a more in-depth analysis of competition from China, the US's largest trading partner and second most popular destination for offshoring (after Mexico) in 2008. We present evidence that both imports from China and offshoring to China are associated with lower US worker wages. Increasing occupational import penetration from China by a 10 percentage point share of a market is associated with a 5.6 percent point wage decline, and increasing occupational offshore exposure to China is associated with a further $1.6 \%$ decline in wages. The results suggest that focusing on imports alone (as in Autor, Dorn, and Hanson (2013)) may understate the role of globalization in contributing to falling US wages.

Lastly, we begin to examine the role played by trade and offshoring in explaining US labor force participation. In the wake of the global financial crisis and the slow recovery, the US has suffered persistently high rates of unemployment relative to historical averages, and generational lows in labor force participation rates. While some of this is due to population aging, the decline in labor force participation is thought to reflect the long-term weakness of the labor market. Many unemployed Americans have discontinued their job searches, but the extent to which this is related to globalization is unclear. We hypothesize that for workers who 
participated in the "glory days" of American manufacturing, the offered wages available in the market where they could secure employment do not justify working or continuing a job search.

In our empirical analysis, we examine the relationship between trade, offshoring, and labor force participation. We find a robust negative correlation between offshore exposure to China and labor force participation, within age-year-occupation cells but interestingly, a positive relationship between labor force participation and import competition from China. The evidence suggests that factors associated with computer use and increasing capital intensity are much more significantly associated with declining employment. Consistent with Harrison and McMillan (2011), we find very small effects of globalization on labor force participation and large effects of computer use and the price of investment goods. Falling investment goods prices are associated with increasing use of capital. Greater use of computers and capital equipment is associated with lower employment, higher unemployment, and lower labor force participation. Taken together, our results indicate that while globalization as measured by trade and offshoring is associated with downward pressure on US wages, globalization is not strongly associated with the historically low rates of labor force participation. In fact, import competition appears to be associated with higher rates of labor force participation, higher employment, and lower unemployment.

The paper is organized as follows. Section II describes our data, documents broad trends in trade and offshoring, and presents our empirical specification. Section III presents our main empirical findings regarding the impact of globalization on domestic wages at the occupation versus the industry level. Section IV examines the role of imports from and offshoring to China and other destination countries in labor force participation in the United States. Section V concludes. 


\section{Data Description, Empirical Strategy, and Trends}

\section{A. Data Description}

Our sample of US workers is taken from the Current Population Survey Merged

Outgoing Rotation Groups for 1983-2008, which provides data for over 4.3 million workers who are assigned a consistent classification for their industry and occupation during the period. ${ }^{4}$

Offshore activity in each industry is measured by the total employment of foreign affiliates by US multinationals, separated into high and low-income affiliate locations, as collected by the Bureau of Economic Analysis (BEA). ${ }^{5}$ Our data on import penetration and export shares are taken from Bernard at al. (2006), which we recalculated and updated through 2007. We control for productivity changes that could also affect labor demand as well as wages using the NBER's calculations of total factor productivity provided by Wayne Gray, also updated through 2007. The NBER data also provides measures of the prices of investment goods, capital to labor ratios, and the real price of shipments by industry and year. ${ }^{6}$ These are included in our main specifications to control for technological change that could also affect wage rates. We include occupational exposure versions of these variables, which are generated in a manner similar to the globalization variables. Lastly, we match our worker data with information on computer use

\footnotetext{
${ }^{4}$ We would like to express our gratitude to IPUMS-CPS, which generated a consistent coding scheme of industries and occupations for the period. We use occ1990 in our analysis for coding occupation. We use a tweaked version of ind1990 and create a concordance with the BEA industry scheme for coding industry. All programs and public data are available from the authors upon request.

${ }^{5}$ The BEA sample of multi-national firms accounted for 80 percent of total output in manufacturing in 1980, suggesting that the coverage is fairly extensive. However, using these data we are unable to distinguish between imports from affiliates (arms-length trade between firms) and imports from non-affiliates.

${ }^{6}$ These data were aggregated from the 4-digit to 3-digit SIC level using the employment distribution in 1979. The 3digit SIC level was converted to our industry classification scheme using a concordance provided by David Autor that was a census-based scheme that consistently defined industries for our sample period. A similar method was used to match CPS workers to the trade data.
} 
rates by industry and occupation from CPS computer supplements conducted during our sample period $(1984,1989,1993,1997,2000)$. Using the available surveys, we interpolate computer use rates for intervening years. Since the CPS changed the nature of the computer question following 2000 , we freeze computer use rates by occupation at the rates in 2002. Summary statistics for the individual worker sample matched to our offshoring, trade, technology, and price data are available in Table 1 for 1983 and 2007.

We use Autor et al.'s (2003) distinction between routine and non-routine tasks to allow us to separately identify the impact of different measures of globalization across different types of workers. ${ }^{7}$ To the extent that routine tasks are more easily offshored or replaced with imports, we would expect globalization to have a larger impact on workers performing these types of tasks. While Autor et al. (2003) use routine-ness to designate which jobs can be easily performed by computers, we would argue that routine jobs are also more readily codified, communicated, and consequently transferred overseas. Examples of these jobs include attaching hands to faces of watches, sewing fasteners and decorative trimming to articles of clothing, and services tasks that we think of as offshorable, such as answering telephones. This is described in greater detail in Ebenstein et al. 2014.

\section{B. Empirical Strategy}

Our empirical strategy is to regress $\log$ wages of worker $i$ in industry $j$ in period $t\left(W_{i j t}\right)$ on lagged measures of exposure to offshoring and international trade $\left(G_{i j t-1}\right)$ using annual data from

\footnotetext{
${ }^{7}$ These data were also provided by David Autor and are used in Autor et al. (1998). Autor et al. (2003) describe routine jobs as "tasks that can be expressed using procedural or 'rules-based' logic, that is, codified in a fully specified sequence of logical programming commands ("If-Then-Do" statements) that designate unambiguously what actions the machine will perform and in what sequence at each contingency to achieve the desired result."
} 
1983 to 2008 , first at the industry level and subsequently at the occupation level, which we define below.

We use lagged measures of exposure to offshoring and trade for two reasons. First, since offshoring requires time to implement, and wage adjustment is not instantaneous, it is unlikely that the causal effect of offshoring on wages will play out within a single calendar year. Second, within a given year, offshoring, trade exposure, and wages are likely to be affected by simultaneous shocks. In our basic specification in Tables 2 and 3, we use four measures of exposure to offshoring and international trade: offshoring to low-income affiliate locations, offshoring to high-income affiliate locations, export shares, and import penetration. Offshoring is measured as the log of summed employment in sector $j$ and year $t$ by US multinationals in low and high-income countries.

There are three additional challenges to identifying the causal effect of globalization on wages. First, the industries that are most likely to globalize may also be those with lower wages or greater volatility. We address this concern by including industry fixed effects $\left(I_{j}\right)$ in our specification. Second, globalization and wages may be jointly affected by common time-varying shocks, such as the business cycle and exchange rate fluctuations. We control for these by including time fixed effects $\left(d_{t}\right)$. Third, we control for time-varying shocks at the industry level that could be confounded with changes in globalization by adding a number of additional controls. $T F P_{j t-1}$ captures changes in productivity by industry and year that could affect demand for labor. We also control for productivity changes including two (arguably) exogenous measures, the price of investment goods and computer use rates. The price of investment goods $P I N V_{j t-1}$ captures in part the role of falling computer prices and the potential impact of laborsaving technology on labor market outcomes. We also control for industry factor intensity 
(lagged capital to labor ratio $\left.K L R A T I O_{j t-1}\right)$ and computer use rates by industry and year $\left(C O M P_{j t}\right)$ to account for contemporaneous changes in an industry's wage rate based on the ability to substitute for labor with computers. ${ }^{8}$ Finally, we control for individual characteristics of the labor force by including age, sex, race, experience, education, and location $\left(Z_{i j t}\right)$. The estimating equation at the industry level (for manufacturing only) is given by:

$W_{i j t}=\beta_{0} Z_{i j t}+\beta_{1} G_{j t-1}+\beta_{2} T F P_{j t-1}+\beta_{3} P_{I N V_{j t-1}}+\beta_{4}$ KLRATIO $_{j t-1}+\beta_{5} \operatorname{COMP}_{j t}+\beta_{6} d_{t}+\beta_{7} I_{j}+\varepsilon_{i j t}$.

To examine the relationship between wages and globalization at the occupation level, we retain the same setup as in (1a) but expand the sample to include workers outside of manufacturing. We also modify the $G$ vector to create a measure of occupational exposure to offshoring or trade. Each variable in the $G$ vector was created from a merged dataset of BEA offshore employment data, trade data, and CPS monthly outgoing rotation group individual-level data, by industry and year. We calculate for each occupation its exposure to trade using as weights the distribution of workers employed in this occupation across industries in 1983. For each occupation $k$ and industry $j$, we have: $\alpha_{k j 83}=\frac{L_{k j 83}}{L_{k 83}}$ where $L_{k j 83}$ is the total number of workers in occupation $k$ and industry $j$ in 1983 , and $L_{k 83}$ is the total number of workers across all industries in occupation $k$. We then calculate occupation-specific import penetration in year $t$ for occupation $k$ as:

$$
\sum_{j=1}^{J} \alpha_{k j 83} I M P_{j t},
$$

\footnotetext{
${ }^{8}$ Our results are similar if we control for computer use rates in the previous year.
} 
where $\mathrm{IMP}_{j t}$ is the measure of import penetration for goods in industry $j$ in year $t$. We continue to control for technological changes by industry, and set these technological changes equal to unity for workers outside of manufacturing. ${ }^{9}$

This leads to a specification of the form:

$(1 b)$

$W_{i j k t}=\beta_{0} Z_{i j k t}+\beta_{1} G_{k t-1}+\beta_{2}$ TFP $_{j t-1}+\beta_{3}$ PINV $_{j t-1}+\beta_{4}$ KLRATIO $_{j t-1}+\beta_{5}$ COMP $_{k t}+\beta_{6} d_{t}+\beta_{7} I_{j}+\beta_{8}$ Occupation $_{k}+\varepsilon_{i j k t}$

where $k$ indexes the worker's occupation, and workers within the same $k$ occupation may be in different $j$ industries. ${ }^{10}$ For workers outside of manufacturing, the control variables for TFP, PIINV, and REALSHIP are produced at an occupation level using the same method as with trade and offshoring, where movement is based on the weighted average of change across industries, where the weights are taken from the occupation's distribution across industries.

Our $G$ vector and technology control variables are now an occupation-specific measure for each worker, and we have added occupation fixed effects to absorb variation specific to time invariant features of occupations. Note that we also control for variation in computer use rates by occupation and year, which is meant to account for wage changes driven by the ability of some occupations to benefit from computer technology (Autor et al. 1998). We will estimate this specification for routine and non-routine workers separately. ${ }^{11}$

\footnotetext{
${ }^{9}$ An alternative approach would be to create occupation-specific measures of each of our control variables. In the online appendix, we estimate models with occupational-specific measures of TFP, the price of investment goods, and the capital to labor ratio. The results are qualitatively similar to the results presented in the main text. These are presented in Table A9.

${ }^{10}$ For workers outside of manufacturing, the control variables for TFP, PIINV, and REALSHIP are not available and are therefore assumed constant in our main specifications.

${ }^{11}$ One important implicit assumption in our approach is that barriers to changing occupations are similar across routine and non-routine occupations. Kambourov and Manovskii (2008) show this to be the case. They also decompose occupation switching across routine and non-routine occupations and show that between 1968 and 1997 workers were not able to escape routine occupations by switching into non-routine ones.
} 


\section{C. $\quad$ Trends in Offshoring, Trade, Employment, and Wages}

In this section we outline broad trends in the data for employment, wages, and the relationship between wages and measures of globalization. In Figure 1, we compare the trends in employment and wages in the manufacturing sector alongside the same trends in the service sector between 1979 and 2012. We present these trends separately for workers performing routine and non-routine tasks. Total manufacturing employment (using the CPS employment numbers) fell from 22 to below 16 million from 1979 to 2008, with rapid declines at the beginning of the early 1980s and in the late 1990s. Within manufacturing, the labor force has become increasingly high-skilled with a large decline of about 8 million workers in routine occupations. While there was a modest increase of 1.5 million between 1979 and 1999 in the number of workers performing non-routine occupations, this increase evaporated in the ten years that followed.

In contrast, demand for both types of workers continued to grow in the service sector, and many of the displaced routine manufacturing workers may have found employment in the service sector. These trends have important implications for the US wage distribution. As shown in the bottom of Figure 1, where we report the real hourly wage among CPS workers, manufacturing workers enjoyed a large wage premium during the entire period among both routine and nonroutine workers. Insofar as manufacturing provided an opportunity to earn high relative wages even for low-skill workers - the fall in manufacturing employment might also have played a role in increasing US income inequality during the period. ${ }^{12}$

\footnotetext{
${ }^{12}$ See Autor et al. (2008) for a review of these trends. It is worth noting that while the trends in Figure 1 are informative, they do not control for other factors that affect income, such as sex, age, and experience. We redid the trends in wages by educational attainment using wage residuals. These wage residuals were computed using Lemieux's (2006) approach for each educational category separately. We also added industry dummies to control for inter-industry wage differentials. The wage residuals show similar trends, with falling wage premia for less
} 
The three panels displaying wage trends exhibit significant differences during the sample period. Real wages grew in the 1980 s, fell or stagnated in the 1990 s, and then began to increase around 1995-1996. Over the entire period, the gap between manufacturing and service wages narrowed, particularly from the mid-1990s onwards. The persistently higher wage offered in manufacturing relative to services during the entire sample period, and present in both routine and non-routine occupations, is an important stylized fact that we emphasize in this paper. As we will show in Section III, much of the impact of globalization has operated by shifting workers from the higher paid manufacturing sectors to the lower paid service sectors in the US labor market.

In Figure 2, we turn to an examination of how offshoring and trade may be related to these employment and wage trends within manufacturing and in the overall economy. As shown in Figure 2, foreign affiliate employment in low-income countries by US multinationals nearly tripled from a base of less than a million workers to almost 3 million workers, while affiliate employment in high-income countries remained roughly constant. The increase in developing country activity was accompanied by a reduction in the US workforce domestically from approximately 22 to 16 million from the beginning of the sample period to 2008 when our data on trade and offshoring end.

In Figure 3, we report changes in the distribution across destination regions for offshoring activity. The results show significant increases for Mexico, China, India and other low income destinations. In Section III we focus on these three countries, which have received significant attention and which represent important offshore destinations for US multinationals. Means of the different variables used in the analysis are reported in Appendix Table A1 


\section{Offshoring, Trade, and the Impact on Domestic Workers}

\section{A. Wage Impacts of Offshoring and Trade at the Industry versus Occupation Level}

In Table 1, we present our main results showing how the impact of offshoring and trade differ when using industry versus occupation measures of exposure. In the first four columns, we present our estimates for equation (1a) which defines exposure to trade or offshoring at the industry level. In the last four columns, we redo the analysis using our occupation exposure measure, as outlined in equation (1b). Note that the standard errors are clustered by industry and five year period in columns (1) through (4) and by occupation and five year period in the last four columns. Industry regressions include industry fixed effects and occupation regressions include occupation as well as industry fixed effects.

Columns (1) through (4) of Table 1 identify the impact on wages of workers in industries which were more exposed to international trade or offshoring during the 1984 through 2008 period. ${ }^{13}$ In these four columns, only workers within the manufacturing sector are included in the estimation. The results suggest a very limited role for offshoring or trade in explaining log wages. There is no statistically significant relationship between low-income-affiliate employment, lagged export share, or lagged import penetration and industry-level wages; indeed, the point estimates are close to zero. We find a modest relationship between exports and wages, suggesting that workers with intermediate routine tasks gain the most from export demand. However, this evidence is from only a single significant coefficient, and in general, the table indicates that trade has had an only mild effect on workers within manufacturing. In these first four columns, which rely on differences in exposure to trade or offshoring across industries, the

\footnotetext{
${ }^{13}$ Note that we exclude 1983 for consistency with our occupation results, which can only be estimated from 19842002, since occupation was only coded consistently from 1983 and on, and we are using lagged measures of our independent variables.
} 
evidence indicates that trade has no substantial negative effect on worker wages for either routine or non-routine workers.

In columns (5) through (8) of Table 1, we present results from specification (1b) where we measure exposure to trade or offshoring at the occupation level. The effects of both offshoring and trade are larger in sign and generally significant at the five percent level. In the first row of column (5), the coefficient on low-income affiliate employment indicates that a ten percent increase in employment offshored within an occupation is associated with a 0.27 percent wage reduction for U.S. workers. For workers in the most routine occupations, we find that a ten percent increase in low-income affiliate employment abroad is associated with a 0.68 percent decline in domestic wages, whereas workers in less routine occupations were largely unaffected by offshoring. Although the magnitude of the effect is small, the results are consistent with the following interpretation: workers in low-income locations perform the same tasks that lowskilled workers perform in the US and are therefore substitutes for workers in the US.

We also find a positive effect of lagged high-income affiliate employment on wages, for all but the least routine workers. Workers in high-income locations appear to perform tasks that are complementary to workers in the US and so expansion of employment in high-income countries can benefit domestic workers who engage in routine tasks. These results, which are consistent with Harrison and McMillan (2011), are robust to a range of specification choices, including whether we use prices of imported and exported goods instead of quantities, and our chosen set of control variables, such as controlling for the real price of shipments by sector to account for variation in product demand. ${ }^{14}$ The results are qualitatively similar to the results presented here, and are available from the authors.

\footnotetext{
${ }^{14}$ The results indicate that workers with price decreases in their product market have suffered the largest wage declines, with this pattern most pronounced in routine occupations. Similar to our core results, however, this effect is
} 
Our results indicate that a ten percentage point increase in occupational exposure to import competition is associated with nearly a 3 percent decline in real wages for workers. For intermediate routine workers, a 1 percentage point increase in import penetration translates into a 1.5 percentage point reduction in wages. While some occupations have experienced no increase in import competition (such as teachers), import competition in other occupations (such as shoe manufacturing) has increased by as much as 40 percentage points. ${ }^{15}$ For occupations with significant export activity, wages are positively linked to export growth. For these workers, a ten percentage point increase in export share at the occupation level is associated with a 6.1 percent increase in wages over the sample period. The gains from growing exports are largest for routine workers and actually negative for less routine workers, which is a puzzle.

Krugman (2008) and Feenstra (2008) both hypothesize that the effects of international trade and offshoring may have increased recently relative to earlier decades. In Table 2, we split the sample into earlier and later time periods. In particular, we allow the impact of globalization to vary for 1983-1990, 1991-1999, and 2000-2008. We also explore whether the impact of globalization varied by gender, union status, education, and age.

The results in Table 2 indicate that there is no significant association between log wages and employment in offshore locations in the early years of our sample (1983-1990, 1991-1998). However, in the later periods (2000-2008) worker wages are negatively and significantly associated with increased offshore employment in low-income affiliate locations. In the years 2000-2008, the coefficient estimates in the third row of Table 2 indicate that a 10 percent

only observed using occupational exposure measures of import price changes. Special thanks to Lawrence Edwards for generous use of his price series data on imports. Other specifications we have tested include removing measures of TFP and controlling for price changes in the service sector using a CPI/PPI index, both of which provide results similar to those presented in Table 2. Likewise, the results including the real price of shipments are similar to the results in Table 2.

${ }^{15}$ See the online appendix for further information on import exposure by occupation. 
increase in low-income affiliate employment is associated with a 0.4 percent decrease in domestic wages. These negative coefficients contrast with the positive coefficients on highincome affiliate employment: a 10 percent increase in high-income affiliate employment is associated with a 0.3 percent increase in domestic wages.

Table 2 also reports the coefficient on lagged imports and exports, measured at the occupation level. The point estimates for occupation-specific import penetration are statistically significant for some of the specifications, For example, among women, a 10 percentage point increase in import penetration is associated with a $2.28 \%$ wage decline, significant at the $10 \%$ level. The evidence also points to a positive and significant association between export share and domestic wages.

In Table 2, we also explore heterogeneity in our results across different demographic groups. Anecdotes in the popular press and elsewhere suggest that women, union workers, less educated workers and older workers may have been disproportionately affected by international competition. If we restrict the sample to either women or union workers, there is no evidence that their wages were more negatively affected than the rest of the sample. In fact, the wages of unionized workers appear to have been relatively unaffected by either export activity or import competition. Women seem to have significantly benefited from export activity.

The wages of workers without higher education and older workers do appear to have been disproportionately affected by offshoring activities, as the point estimates are larger for these groups of workers. The estimates in Table 2 indicate that the largest negative and significant effects of offshore employment were concentrated among older or less educated workers. In contrast, the largest (negative) impacts of import competition and (positive) effects 
of export activity on wages are concentrated among individuals under 35 years of age and college educated workers.

\section{B. Mechanisms for Differences between Occupation and Industry Results}

In this section, we identify mechanisms for the differences between industry-level and occupation-level exposure to offshoring and trade. Our evidence and previous research suggests that switching occupations, but not sectors within manufacturing, significantly affects worker wages. In this section, we directly link changes in occupations for the same individual with changes in globalization and explore the impact on wages. We begin by examining the wage consequences of switching industries, sectors, and occupations using a panel of CPS workers who are followed for more than one period.

To explore the impact of switching sectors or occupations, we construct a sample of manufacturing workers observed in CPS samples in consecutive years between 1983 and 2008. We regress the change in log wages between period $t$ and $t+1$ for a given worker on an indicator for switching industries, sectors, or occupations. We also include a rich set of controls for the worker's age, sex, education, race, union status in the first period, and industry in the first period. If occupational exposure to globalization puts downward pressure on wages by inducing workers to exit high wage jobs in manufacturing, then we would expect to see this in the data. In particular, we would expect wages of manufacturing workers who retain their jobs to be relatively unaffected by globalization, whereas those who shift sectors or occupations to be negatively affected. In Table 3, we examine the impact on a worker's wages of shifting across manufacturing sectors, leaving manufacturing, and leaving an occupation within manufacturing. The first panel (Panel A) of Table 3 examines the impact on wages for workers 
who switch industries but remain within manufacturing during both periods. Consistent with the results in Table 1, we see that switching sectors (from textiles to steel, for example) but remaining in the same occupation within manufacturing is not associated with significant wage changes. For all types of occupations, including the most routine occupations, switching industries within manufacturing has no significant impact on worker wages. In Panel B of Table 3 , we examine how wages of an individual are affected when that worker leaves manufacturing. On average, a worker who leaves the manufacturing sector experiences a real wage decline of three percent from one period to the next. The documented wage decline for an individual worker in the CPS who leaves manufacturing is consistent with Figure 1 showing a wage premium for workers in manufacturing. However, unlike Figure 1, the regression results in Table 3 control for a wide range of individual worker characteristics.

The last panel of Table 3 shows the highest real wage declines for workers who leave manufacturing and switch occupations. On average, workers who leave manufacturing and switch occupations experienced a real wage decline of 4 percent, with a range of 2.7 to 8.5 percent. To summarize, Table 3 shows that (1) remaining in the same occupation but switching industries within manufacturing does not significantly affect a worker's wages (2) leaving manufacturing but remaining within the same occupation has a negative impact on an individual's real wage and (3) leaving manufacturing is particularly costly for workers who also switch occupations.

The evidence presented in Table 3 is consistent with the results presented earlier in this paper but does not establish a direct link with trade or offshoring. In Ebenstein, Harrison, McMillan and Phillips (2014), we explore direct linkages between switching sectors or occupations and our different globalization measures. We decompose the results in the last four 
columns of Table 2 into manufacturing only and services only. The impact of offshoring and trade is significant using the occupational exposure measure for both manufacturing (only) and services (only). ${ }^{16}$ What is particularly noteworthy is that the coefficients are the most negative for services. Paul Krugman has argued that globalization could not possibly affect wage outcomes in the United States because manufacturing is too small relative to the other sectors of the economy, so the "tail can't wag the dog". However, our results indicate that, in fact, the significant exposure at the occupational level to trade or offshoring does affect service sector wages. This is likely to operate both through the falling wages of workers who have moved from manufacturing to services (as documented in Figure 1 and Table 3) as well as by putting downward pressure on the wages of workers in services as labor supply in services shifts out to absorb workers formerly in manufacturing.

Our results are consistent with work by Kambourov and Manovskii (2008, 2009a, 2009b) who find large wage declines among workers who switch occupations; this evidence suggests an important role for occupation-specific human capital in a worker's wage profile. Kambourov and Manovskii (2008, 2009a, 2009b) also argue that occupation-switching may be an important cause of the increase in US wage inequality, as younger workers are missing out on the benefits that accrue to occupational tenure enjoyed by workers in previous decades. Insofar as this is partly driven by competition from overseas, this highlights another mechanism by which offshoring may be responsible for declining US wages and increasing wage inequality.

\section{Offshoring to Low Income Countries and Labor Force Participation}

\section{A. Descriptive Statistics}

\footnotetext{
${ }^{16}$ Those results are available in the Appendix to Ebenstein et al (2014).
} 
Some theories of foreign investment emphasize the horizontal nature of FDI and the fact that it substitutes for international trade. Other theories emphasize the vertical nature of FDI and focus on offshoring as an outcome of strategic and profit-maximizing location decisions to increase the efficiency of global value chains. In this section, we begin our discussion of the impact of offshoring on US wages by summarizing the patterns in trade and offshoring in 2007, as reported in Table 4.

Table 4 reports the sectors with the greatest activity in imports, exports, and offshoring. Imports and exports are measured as a share of domestic production, while offshore activities are measured using total foreign affiliate employment. All the data are calculated for 2007, the latest year for which we have information on both trade and offshoring. Import penetration is highest in lower value added industries, and sectors which are traditionally thought to be labor-intensive. This includes toys, leather products, apparel and other textiles, and metal products.

In contrast, offshoring occurs primarily in high value added industries, such as motor vehicles and electronics. There are many possible reasons for this. Historically, the sectors where offshore employment for US multinationals has been highest in Mexico, China, India and other emerging markets are those where domestic tariffs in those destinations were the highest. This means that in order to access those markets, US companies needed to establish offshore operations there instead of exporting which was more challenging given the size of local tariffs or other restrictions on entry. Foreign investment promotion efforts in many developing countries have also targeted these types of activities, as countries like India and China have sought to grow their own motor vehicle, electrical machinery, and other higher tech sectors. This evidence, while preliminary, may indicate that offshoring could expose a larger and different class of workers to international competition than trade alone. 


\section{B. Occupational Exposure by Country of Destination}

In Tables 5 and 6, we redo our basic specification but replace the offshoring measure with location-specific measures of offshore activity. In Table 5 we present estimates by time period of the impact of offshore employment in China, India, and Mexico. While in Table 5 the results are reported for each country in separate regressions, we also estimate the equation including all country destinations concurrently. While the point estimates remain the same, the significance falls due to multicollinearity. Consequently we only report the specifications in Table 5 .

If we compare the coefficient estimates in Tables 1,2 , and 5 , there is no evidence that offshoring to China, India, or Mexico is more likely to put downward pressure on domestic US wages than offshoring to other low income country destinations. In fact, the evidence is consistent with offshoring to China being less costly or not significantly different than offshoring to other low income country destinations. Similarly, offshoring activities in Mexico and India, the other top destinations for offshoring by US multinationals as measured by the number of employees at offshore affiliates, do not exert significantly larger downward pressure on US wages than offering to other low income regions. The largest coefficient is for Mexico, which remained the location with the highest number of affiliate employees for US multinationals throughout the sample period (see Figure 3).

In Table 6 we compare the impact of import competition from China with offshoring to China by including both measures in the same regression. Other controls (see Tables 1 and 2), are also included but not reported. The results show that the negative impact of import competition from China did not become significant until the last decade (2000-2008), when China joined the WTO and trade volumes significantly increased. The coefficient estimate, - 
0.562, is two to three times the magnitude of the import coefficients reported in Tables 1 and 2. The coefficient indicates that a 10 percentage point increase in import competition from China is associated with a 5.6 percentage point decline in wages of workers in occupations affected by those imports.

In contrast, the impact of offshoring to China is small in magnitude. In comparison to offshoring activities in other low income regions, the impact is also smaller, if we compare the point estimates in Table 6 with those in Tables 1 and 2 . The coefficient, -0.0158 , indicates that a ten percent increase in offshore employment in China would be associated with a small wage decline of .16 percent. The evidence in Table 6 indicates that the impact through 2008 of Chinese competition on US wages was felt most significantly via imports and not through offshoring activities of US companies to China. The point estimates on offshoring activities through 2008 were significantly below those for other offshore destinations, including Mexico and India.

\section{Results for Labor Force Participation}

Table 7 examines the determinants of labor force participation rates using the CPS data. Labor force participation is defined as the share of the labor force either employed or actively seeking employment. Labor force participation is calculated at the three digit occupation by year by five year age group cell for ages 15 through 64 . The measure is the labor-force participation rate among workers in each of these cells weighted by their sample weight. We then regress labor force participation on all of the variables included in Table 1. We report results for all individuals as well as for individuals between the ages of 15 and 34, as there has been a significant decline in labor force participation for this age group. 
The results, reported in the first two columns of Table 7, indicate that import competition is positively and significantly associated with labor force participation, as measured by import shares. The most significant determinant of labor force participation (apart from individual characteristics such as sex, age, and experience which are included as controls) is the use of computers in the occupation. Occupational exposure from offshore employment in China is also significantly and negatively associated with US labor force participation, but the point estimates indicate a very small effect.

The last four columns of Table 7 decompose labor force participation into its two components, individuals who are employed and those who are actively seeking employment (i.e. the unemployed). We felt that it would be useful to decompose labor force participation into these two components, since demand shocks are likely to have opposite effects on the percentage of individuals who are currently employed versus those who are seeking employment. The results in the last four columns of Table 7 show that the most important determinants of employment are computer use rates (negative) and investment goods prices (positive). These results are consistent with a viewpoint that technological change is leading to increasing use of computers or capital equipment to replace labor. Offshoring, on the other hand, is not an important determinant of employment or unemployment.

The results for trade, as measured by imports and exports, are quite different for labor force participation than they are for wages. While neither exports nor imports are significantly associated with labor force participation, they are significantly associated with employment and unemployment rates. The evidence indicates that higher import penetration is associated with higher rates of labor force participation, and lower rates of unemployment. These results are contrary to received wisdom. The evidence is equally surprising for exports: higher export 
shares in the previous period are associated with higher rates of unemployment, although the relationship with labor force participation in the first two columns and employment rates in the middle two columns is not statistically significant at conventional levels. We explored the robustness of the trade results in Table 7 by adding a number of controls, including controls for domestic production. The results remained unaffected.

We further explore the robustness of these results using the subset of the CPS that follows the same worker over time. In Tables 8 and 9 we are able to identify workers who worked in the previous time period but stopped working in the current year. In particular, we would like to see whether employment for the same individual over time is affected by our measures of globalization. The results at the individual level are useful because they allow us to control for individual fixed effects which may not be captured in Table 7.

The results in Tables 8 and 9 are consistent with the earlier results presented in Table 6 on the determinants of employment. Individuals are more likely to stop working if they are in occupations that are more exposed to offshoring in low income regions. Conversely, these individuals are less likely to stop working if they are in occupations where high income affiliate employment is growing. Consistent with the results in Table 7, the evidence indicates that greater import shares are associated with a lower likelihood of leaving employment. When we split the sample into the degree of routineness of the occupation, we see that the results on import penetration are driven by the least routine workers. Increasing import penetration is associated with a higher likelihood of employment for non-routine workers, implying complementarity between non-routine activities and imports. The results are similar in Table 9, which replaces low income offshore employment with offshore employment in China. 


\section{Conclusion}

This paper makes several contributions. First, it builds on the analysis in Ebenstein et al (2014) by focusing on occupational exposure instead of industry-level exposure to identify the wage effects of competition from international trade and offshoring activities through 2008 . We show that with China's entry into the WTO in late 2001, our results remain significant and robust. We also present results that indicate the mechanisms for differences in industry versus occupational exposure. We present evidence that globalization has led to the reallocation of workers away from high wage manufacturing jobs into other sectors and other occupations, with large declines in wages among workers who switch, explaining the large differences between industry and occupational analyses.

Our data on offshoring from the BEA reveals differences in both the timing of offshoring, and the industries that participate in offshoring, relative to conventional trade in goods.

Offshoring is a more recent phenomenon and has grown significantly faster than trade in recent years, with implications for US wages and employment. Offshoring activities allow US multinational corporations to separate the production process for any given good into high-skill and low-skill tasks, and thereby take advantage of cheaper labor overseas, even for high value added goods. This is particularly relevant for industries such as motor vehicles, which historically had powerful unions and were able to demand high wages for their workers.

The second contribution is that we are able to consider offshoring by destination country separately from imports. We find that the most significant low income offshore destinations, measured in terms of total employment offshore by US parents, are not associated with larger downward pressure on US worker wages than offshoring to other low income regions. 
Third, we examine the role of China's entry into the global economy in much greater depth. Since China's accession to the WTO in 2001, scholarship has largely focused on China's growing role in international trade and its potential impact. In this paper, we compare for the first time the impact of both import competition from China and offshore activities by US multinationals in China. Analyzing wages of individuals who are actively in the labor force indicates that competition via international trade from China is economically much more important as measured by downward pressure on US wages than offshoring activities in China. The point estimates indicate that a one percentage point increase in import penetration from China during the 2000 through 2008 period would have been associated with a .6 percentage point decline in the wages of affected US workers. In contrast, a one percent increase in offshore employment of US affiliates in China was associated with a .02 percent decline in wages.

Finally, we explore the impact of trade and offshoring on labor force participation. We demonstrate that neither offshoring nor international trade are associated with a significant reduction in labor force participation. Our results indicate that the most important factors associated with a reduction in US labor force participation during the sample period were computer use rates or increasing capital intensity, and that offshore activities to China or elsewhere played a very small role. Trade is positively associated with labor force participation between 1983 and 2008. Our preliminary results indicate that the "discouraged worker effect" is unlikely to be linked to increasing import competition, from either China or elsewhere. 


\section{References}

Artuç, Erhan, Shubham Chaudhuri, and John McLaren. 2010. "Trade Shocks and Labor Adjustment: A Structural Empirical Approach." American Economic Review, 100(3): 1008-1045.

Autor, David H., Lawrence F. Katz and Alan B. Krueger. 1998. "Computing Inequality: Have Computers Changed the Labor Market?” Quarterly Journal of Economics, 113: 1169-1213.

Autor, David H., Frank Levy, and Richard Murnane. 2003. "The Skill Content of Recent Technological Change: An Empirical Exploration." Quarterly Journal of Economics, 118: 12791334.

Autor, David H., Lawrence F. Katz and Melissa S. Kearney. 2008. "Trends in US Wage Inequality: Revising the Revisionists." Review of Economics and Statistics, 90: 300-23.

Autor, David H. David Dorn, and Gordon H. Hanson. 2013. "The China Syndrome: Local Labor Market Effects of Import Competition in the United States." American Economic Review, 103(6): 2121-68.

Bernard, Andrew, J. Bradford Jensen and Peter Schott. 2006. "Survival of the Best Fit: Exposure to Low-Wage Countries and the (Uneven) Growth of US Manufacturing." Journal of International Economics, 68: 219-237.

Cosar, A. Kerem, "Adjusting to Trade Liberalization: Reallocation and Labor Market Policies," October 2010. University of Chicago Booth School of Business, unpublished manuscript.

Desai, Mihir, C. Fritz Foley, and James R. Hines. 2009. " Domestic Effects of the Foreign Activities of US Multinationals." American Economic Journal: Economic Policy, 1(1): 181-203.

Ebenstein, Avraham, Ann Harrison, Margaret McMillan, and Shannon Phillips, "Estimating the Impact of Trade and Offshoring on American Workers using the Current Population Surveys", Review of Economics and Statistics, 96(4): 581-595, October 2014.

Feenstra, Robert C. 2008. "Offshoring in the Global Economy." Presented at the Stockholm School of Economics, September 17-18 as the Ohlin Lecture. Available for download at the author's website.

Feenstra, Robert C. and Gordon H. Hanson. 1999. "The Impact of Outsourcing and HighTechnology Capital on Wages: Estimates for the US, 1972-1990.” Quarterly Journal of Economics, 114(3): 907-940.

Freeman, Richard. 1995. “Are Your Wages Set in Beijing?” Journal of Economic Perspectives, 9(3) 15-32.

Grossman, Gene M. and Esteban Rossi-Hansberg. 2008. "Trading Tasks: A Simple Theory of Offshoring.” American Economic Review, 98(5): 1978-1997. 
Harrison, Ann and Margaret McMillan. 2011. "Offshoring Jobs? Multinationals and U.S. Manufacturing Emploment." The Review of Economics and Statistics, 93(3): 857-875.

Hummels, David, Rasmus Jørgensen, Jakob R. Munch, and Chong Xiang. 2011. "The Wage Effects of Offshoring: Evidence from Danish Matched Worker-Firm Data." NBER Working Paper No. 17496.

Jensen, J. Bradford and Lori G. Kletzer. 2005. "Tradable Services: Understanding the Scope and Impact of Services Offshoring." Working Paper Series Number WP 05-9.

Kambourov, Gueorgui and Iourii Manovskii. 2008. "Rising Occupational and Industry Mobility in the United States: 1968-97." International Economic Review, 49(1): 41-79.

Kambourov, Gueorgui and Iourii Manovskii. 2009a. "Occupational Specificity of Human Capital.” International Economic Review, 50(1): 63-115.

Kambourov, Gueorgui and Iourii Manovskii. 2009b. "Occupational Mobility and Wage Inequality.” Review of Economic Studies, 76: 731-759.

Katz, Lawrence F. and Lawrence H. Summers. 1989. "Industry Rents: Evidence and Implications." Brookings Papers on Economic Activity, Microeconomics 1989: 209-290.

Krueger, Alan B. and Lawrence H. Summers. 1988. "Efficiency Wages and the Inter-Industry Wage Structure." Econometrica 56 (2): 259-293.

Krugman, Paul. 2008. “Trade and Wages, Reconsidered.” Brookings Papers on Economic Activity, Spring, 103-154.

Lemieux, T. 2006. "Increasing Residual Wage Inequality: Composition Effects, Noisy Data, or Rising Demand for Skill?” The American Economic Review 96 (3): 461-498.

Menezes-Filho, Naércio and Marc-Andreas Muendler. 2011. "Labor Reallocation in Response to Trade Reform." NBER Working Paper No. 17372.

Pierce, Justin and Peter Schott. 2012. "The Surprisingly Swift Decline of U.S. Manufacturing Employment”. NBER Working Paper No. 18655.

Trefler, Daniel and Runjuan Liu. 2011. "A Sorted Tale of Globalization: White Collar Jobs and the Rise of Service Offshoring." NBER Working Paper No. 17559.

United States Department of Labor, Employment and Training Administration. 1977.

"Dictionary of Occupational Titles: Fourth Edition." Washington, DC: US Government Printing Office. 
Table 1: OLS Estimates of Wage Determinants using Industry and Occupational Exposure to Offshoring and Trade, 1983-2008

Dependent Variable: Log Wage

Offshoring and Trade Measured by

Industry-Specific Exposure, Manufacturing Only

All Most

Occupations

$\begin{array}{ccc}\text { Most } & \text { Intermediate } & \text { Least } \\ \text { Routine } & \text { Routine } & \text { Routine }\end{array}$

Variable

Lagged log of low income

affiliate employment

Lagged log of high income

affiliate employment

Lagged export share

Lagged import penetration

0.000
$(0.001)$

$$
-0.001
$$$$
\text { (0.001) }
$$

$-0.001$

(0.002)

0.001

(0.002)

$-0.001$

0.004

$(0.002)$

$(0.003)$

$0.0345^{*}$

$-0.001$

$0.0921^{* *}$

(0.038)

$-0.010$

$-0.038$

$(0.027)$

660,500

$(0.012)$

0.49

374,162

196,612

0.39

0.43

R-squared

* significant at $10 \%{ }^{* *}$ significant at $5 \%$. *** significant at $1 \%$
Offshoring and Trade Measured by Occupation-Specific Exposure, All Sectors

\begin{tabular}{|c|c|c|c|}
\hline $\begin{array}{c}\text { All } \\
\text { Occupations }\end{array}$ & $\begin{array}{c}\text { Most } \\
\text { Routine }\end{array}$ & $\begin{array}{c}\text { Intermediate } \\
\text { Routine }\end{array}$ & $\begin{array}{c}\text { Least } \\
\text { Routine }\end{array}$ \\
\hline $\begin{array}{c}-0.0271^{* * *} \\
(0.009)\end{array}$ & $\begin{array}{c}-0.0682 * * * \\
(0.013)\end{array}$ & $\begin{array}{c}0.0256^{*} \\
(0.015)\end{array}$ & $\begin{array}{c}0.0510 * * * \\
(0.015)\end{array}$ \\
\hline $\begin{array}{c}0.0158 * * \\
(0.008)\end{array}$ & $\begin{array}{c}0.0493^{* * *} \\
(0.010)\end{array}$ & $\begin{array}{l}-0.013 \\
(0.014)\end{array}$ & $\begin{array}{c}-0.0178 * * \\
(0.007)\end{array}$ \\
\hline $\begin{array}{c}0.614^{* * *} \\
(0.170)\end{array}$ & $\begin{array}{c}0.750 * * * \\
(0.231)\end{array}$ & $\begin{array}{c}0.995 * * * \\
(0.319)\end{array}$ & $\begin{array}{c}-1.930 * * \\
(0.967)\end{array}$ \\
\hline $\begin{array}{c}-0.277 * * \\
(0.125)\end{array}$ & $\begin{array}{l}-0.041 \\
(0.100)\end{array}$ & $\begin{array}{c}-1.548 * * * \\
(0.340)\end{array}$ & $\begin{array}{c}0.333 \\
(0.877)\end{array}$ \\
\hline $\begin{array}{c}4,315,758 \\
0.51\end{array}$ & $\begin{array}{c}1,529,895 \\
0.42\end{array}$ & $\begin{array}{c}1,786,437 \\
0.53\end{array}$ & $\begin{array}{c}999,426 \\
0.38\end{array}$ \\
\hline
\end{tabular}

Source : Current Population Surveys Merged Outgoing Rotation Groups (1983-2008). See Table A1 for sources of the other variables.

Note : Robust standard errors are reported in parentheses below the coefficient estimates. The workers are taken from CPS samples from 19832008, with their lagged values of the independent variables taken from 1982-2007. The left side of the table is restricted to manufacturing workers and the right-hand side variables shown are based on the exposure to trade within a worker's industry. The right side of the table includes service workers as well, and all right-hand side variables shown are based on the exposure to trade within a worker's occupation. The standard errors are clustered by occupation and 5 year period. The classification of occupations into routine categories is determined by the proportion of tasks which are routine in each occupation, with low being occupations with more than 2/3rd, intermediate being between $1 / 3$ rd and 2/3rd, and high being occupations with less than 1/3rd of tasks designated routine. We also control for the occupation-specific lagged log price of investment, lagged total factor productivity, lagged real price of shipments, and lagged capital to labor ratio. Wage specifications control for a worker's gender, age, race, experience, whether in a union, and include fixed effects for industry (3-digit), occupation (2-digit), year, education and state. Controls for computer use rates are imputed by the worker's occupation using the CPS computer supplement and are included in all specifications. 
Table 2: OLS Estimates of Wage Determinants using Occupational Exposure to Offshoring and Trade Among Subsamples of CPS workers, 1983-2008

Dependent Variable: Log Wage

\begin{tabular}{|c|c|c|c|c|c|c|}
\hline Specification & $\begin{array}{l}\text { Lagged Log } \\
\text { of Low } \\
\text { Income } \\
\text { Affiliate } \\
\text { Emp } \\
\end{array}$ & $\begin{array}{l}\text { Lagged Log } \\
\text { of High } \\
\text { Income } \\
\text { Affiliate } \\
\text { Emp } \\
\end{array}$ & $\begin{array}{c}\text { Lagged } \\
\text { Export } \\
\text { Share } \\
\end{array}$ & $\begin{array}{c}\text { Lagged } \\
\text { Import } \\
\text { Penetration } \\
\end{array}$ & $\begin{array}{c}\text { Obser- } \\
\text { vations } \\
\end{array}$ & $\begin{array}{c}\text { R- } \\
\text { Squared }\end{array}$ \\
\hline 1983-1990 & $\begin{array}{l}-0.014 \\
(0.015)\end{array}$ & $\begin{array}{c}0.008 \\
(0.011)\end{array}$ & $\begin{array}{c}0.51 \\
(0.324)\end{array}$ & $\begin{array}{c}-0.151 \\
(0.168)\end{array}$ & $1,385,716$ & 0.55 \\
\hline 1991-1999 & $\begin{array}{l}-0.015 \\
(0.014)\end{array}$ & $\begin{array}{l}0.0044 \\
(0.012)\end{array}$ & $\begin{array}{c}0.600^{* * *} \\
(0.221)\end{array}$ & $\begin{array}{c}0.016 \\
(0.213)\end{array}$ & $1,434,790$ & 0.51 \\
\hline 2000-2008 & $\begin{array}{c}-0.0395 * * \\
(0.020)\end{array}$ & $\begin{array}{c}0.0302 * \\
(0.017)\end{array}$ & $\begin{array}{l}0.496 * \\
(0.270)\end{array}$ & $\begin{array}{l}-0.170 \\
(0.129)\end{array}$ & $1,495,252$ & 0.47 \\
\hline Female & $\begin{array}{c}-0.0195 * * \\
(0.009)\end{array}$ & $\begin{array}{l}0.0097 \\
(0.008)\end{array}$ & $\begin{array}{c}1.015^{* * *} \\
(0.237)\end{array}$ & $\begin{array}{l}-0.228^{*} \\
(0.119)\end{array}$ & $2,101,141$ & 0.49 \\
\hline Union & $\begin{array}{c}-0.0179 * \\
(0.010)\end{array}$ & $\begin{array}{c}0.007 \\
(0.009)\end{array}$ & $\begin{array}{l}-0.036 \\
(0.189)\end{array}$ & $\begin{array}{c}0.005 \\
(0.130)\end{array}$ & 740,506 & 0.38 \\
\hline $\begin{array}{l}\text { High School } \\
\text { or Less }\end{array}$ & $\begin{array}{c}-0.0466 * * * \\
(0.010)\end{array}$ & $\begin{array}{c}0.0366 * * * \\
(0.009)\end{array}$ & $\begin{array}{c}0.575^{* * *} \\
(0.204)\end{array}$ & $\begin{array}{l}-0.140 \\
(0.121)\end{array}$ & $2,020,735$ & 0.44 \\
\hline $\begin{array}{l}\text { College or } \\
\text { More }\end{array}$ & $\begin{array}{l}-0.006 \\
(0.011)\end{array}$ & $\begin{array}{l}-0.0032 \\
(0.009)\end{array}$ & $\begin{array}{c}0.666 * * * \\
(0.173)\end{array}$ & $\begin{array}{c}-0.373 * * \\
(0.146)\end{array}$ & $2,295,023$ & 0.45 \\
\hline Under 35 & $\begin{array}{c}-0.0280^{* * *} \\
(0.009)\end{array}$ & $\begin{array}{c}0.0155^{* *} \\
(0.007)\end{array}$ & $\begin{array}{c}0.958^{* * *} \\
(0.181)\end{array}$ & $\begin{array}{c}-0.422 * * * \\
(0.142)\end{array}$ & $1,987,180$ & 0.51 \\
\hline Over 40 & $\begin{array}{c}-0.0337 * * * \\
(0.010)\end{array}$ & $\begin{array}{c}0.0209 * * \\
(0.009)\end{array}$ & $\begin{array}{l}0.283^{*} \\
(0.169)\end{array}$ & $\begin{array}{l}-0.097 \\
(0.120)\end{array}$ & $1,873,255$ & 0.47 \\
\hline Over 50 & $\begin{array}{c}-0.0387^{* * *} \\
(0.010)\end{array}$ & $\begin{array}{c}0.0249 * * * \\
(0.009)\end{array}$ & $\begin{array}{c}0.25 \\
(0.172)\end{array}$ & $\begin{array}{l}-0.079 \\
(0.126)\end{array}$ & 851,052 & 0.47 \\
\hline
\end{tabular}

* significant at $10 \% * *$ significant at $5 \%{ }^{* * *}$ significant at $1 \%$.

Source : See Table A1.

Note : Each row represents a separate regression. The independent variables are listed in the column headings, and the subsample of interest is listed in the row heading. Each regression is estimated in the same manner as those reported in Table 1. 
Table 3: Wage Changes Among Manufacturing Workers Observed 2 Periods Who Switch Industry, 1983-2008

Dependent Variable: Log Wage Change Between Periods

All Most Intermediate Least

Occupations Routine Routine Routine

Panel A: Sample of Workers who Stay in Manufacturing both Periods

$\begin{array}{lcccc}\text { Switched Industry } & -0.001 & 0.000 & 0.000 & -0.0133^{* *} \\ \text { Classification (1=yes) } & (0.003) & (0.003) & (0.005) & (0.006) \\ \text { Observations } & 177,759 & 111,833 & 42,600 & 23,326\end{array}$

Panel B: Sample of Workers who Switch Industry Classification between Periods

\begin{tabular}{|c|c|c|c|c|}
\hline $\begin{array}{l}\text { Left Manufacturing } \\
\text { (1=yes) }\end{array}$ & $\begin{array}{c}-0.0269 * * * \\
(0.004)\end{array}$ & $\begin{array}{c}-0.0267 * * * \\
(0.006)\end{array}$ & $\begin{array}{c}-0.0273^{* * *} \\
(0.005)\end{array}$ & $\begin{array}{c}-0.0220^{* *} \\
(0.011)\end{array}$ \\
\hline tions & 208,979 & 130,105 & 50,364 & 28,510 \\
\hline
\end{tabular}

Panel C: Sample of Workers who Leave Manufacturing between Periods

\begin{tabular}{lcccc} 
Switched Occupation & $-0.0406^{* * *}$ & $-0.0276^{* * *}$ & $-0.0393^{* * *}$ & $-0.0852^{* * *}$ \\
(1=yes) & $(0.010)$ & $(0.010)$ & $(0.011)$ & $(0.020)$ \\
Observations & 32,212 & 18,696 & 7,947 & 5,569 \\
\hline
\end{tabular}

* significant at $10 \% * *$ significant at $5 \%$. $* *$ significant at $1 \%$.

Source: Sample is composed of CPS MORG workers observed in two consecutive samples and employed in manufacturing in the first period.

errors are clustered by occupation. All models include year, state and education level fixed effects. Other demographic controls are age, sex, non-white, and union status in the first period. Industries and occupations are defined by 3-digit census classifications. Classification of routine is based on first period occupation. The classification of occupations into routine categories is determined by the proportion of tasks which are routine in each occupation, with low being occupations with more than $2 / 3$ rd, intermediate being between $1 / 3 r d$ and $2 / 3 r d$, and high being occupations with less than $1 / 3 r d$ of tasks designated routine. 
Table 4: Summarizing Patterns in Trade and Offshoring: Five Largest Observations for Each Category

Panel A: Patterns in Exports and Import Penetration

\begin{tabular}{|c|c|c|c|c|c|c|c|}
\hline \multicolumn{2}{|l|}{ Export Share } & \multicolumn{2}{|l|}{ Import Penetration } & \multicolumn{2}{|c|}{ Low Wage Country Import Penetration } & \multicolumn{2}{|l|}{ China Import Penetration } \\
\hline Toys, amusement, and sporting goods & 0.42 & Primary aluminum industries & 0.93 & Toys, amusement, and sporting goods & 0.47 & Toys, amusement, and sporting goods & 0.46 \\
\hline Pottery and related products & 0.39 & Watches \& clocks & 0.88 & Leather and leather products & 0.40 & Leather and leather products & 0.37 \\
\hline Construction machines & 0.32 & Pottery and related products & 0.68 & Apparel and other textiles & 0.37 & Pottery and related products & 0.33 \\
\hline Primary aluminum industries & 0.32 & Apparel and other textiles & 0.63 & Pottery and related products & 0.36 & Household appliances & 0.22 \\
\hline Engines and turbines & 0.25 & Toys, amusement, and sporting goods & 0.59 & Household appliances & 0.22 & Apparel and other textiles & 0.20 \\
\hline
\end{tabular}

Panel B: Patterns in Offshore Employment

Mexico

Motor vehicles and equipmen

Sugar and confectionery products

Electrical machinery and equipment

Radio, TV, and related equipment

Household appliances

China

India

\begin{tabular}{|c|c|c|c|c|c|c|}
\hline 193,498 & Electrical machinery and equipment & 106,971 & Motor vehicles and equipment & 19,760 & Motor vehicles and equipment & 228,401 \\
\hline 100,674 & Motor vehicles and equipment & 55,890 & Sugar and confectionery products & 15,893 & Sugar and confectionery products & 139,338 \\
\hline 63,464 & Drugs & 37,400 & Electrical machinery and equipment & 14,411 & Machinery and Equipment (NEC) & 119,144 \\
\hline 36,412 & Other Machinery (NEC) & 33,223 & Drugs & 12,178 & Apparel and textile products & 82,880 \\
\hline 33,701 & Radio, TV, and related equipment & 32,460 & Other Machinery (NEC) & 10,746 & Tobacco manufactures & 78,860 \\
\hline
\end{tabular}

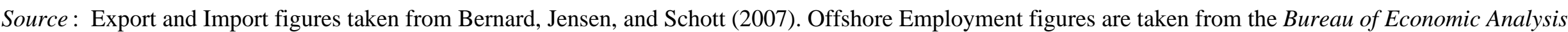
(2007).

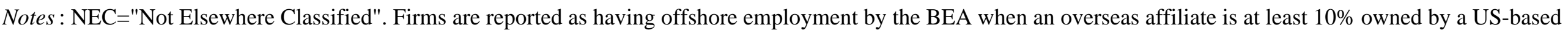
Parent corporation. 


\section{Table 5: Occupational Exposure to Offshoring by Destination}

Dependent Variable: Log Wage

\begin{tabular}{lccc} 
& $1983-1990$ & $1991-1999$ & $2000-2008$ \\
\hline China & $(1)$ & $(2)$ & $(3)$ \\
& -0.028 & 0.0008 & $-0.0197^{* *}$ \\
India & $(0.017)$ & $(0.003)$ & $(0.009)$ \\
& -0.0018 & 0.0020 & $-0.0198^{* *}$ \\
Mexico & $(0.009)$ & $(0.004)$ & $(0.008)$ \\
& 0.000 & -0.0114 & $-0.0290^{* * *}$ \\
Other Low Income & $(0.008)$ & $(0.008)$ & $(0.010)$ \\
Countries & -0.028 & -0.020 & $-0.0486^{*}$ \\
\hline
\end{tabular}

* significant at $10 \%{ }^{* *}$ significant at $5 \%{ }^{* * *}$ significant at $1 \%$.

Source: See Table A1.

Note: Each cell represents the coefficient from a separate regression. The regressions are estimated in the manner described in Table 3, but the measure of offshore employment in low income countries is replaced by employment in China, India, Mexico, and Other Low Income Countries (not China, India, Mexica) in each row respectively, and estimated for the period listed in the column heading. 
Table 6: Comparing the Wage Impact of Imports from China versus Offshoring to China Dependent Variable: Log Wage

\section{(1)}

$-1.61$

penetration from China

Lagged log of Chinese

affiliate employment

Panel B: 1991-1999

Lagged import

$-0.318$

penetration from China

Lagged log of Chinese

affiliate employment

Panel C: 2000-2008

Lagged import

penetration from China

Lagged log of Chinese

affiliate employment

$-0.665 * * *$

(0.226)
(2)

(3)

$-1.26$

$-0.0342 * * *$

(0.013)

$-0.0194 * * *$

(0.007)

$-0.386$

0.002

0.003

(0.002)

$-0.562 * *$

(0.228)

$-0.0194 * * *$

$-0.0158 * *$

(0.007)

* significant at $10 \% * *$ significant at $5 \%$. *** significant at $1 \%$.

Source: See Table A1.

Note: The columns report the results of regressing wages on occupational exposure to (1) import penetration from China, (2) offshoring to China, or (3) including both imports and offshoring simultaneously. The regressions are specified in the manner described in Table 2, except without including low-income offshoring or imports. 
Table 7: Offshoring to China and Labor Force Participation, 1983-2008

\begin{tabular}{|c|c|c|c|c|c|c|}
\hline \multirow[t]{2}{*}{ Dependent Variable: } & \multicolumn{2}{|c|}{ Participating (1=yes) } & \multicolumn{2}{|c|}{ Employed (1=yes) } & \multicolumn{2}{|c|}{ Unemployed (1=yes) } \\
\hline & All & Ages 15-34 & All & Ages 15-34 & All & Ages 15-34 \\
\hline & (3) & (4) & (1) & $(2)$ & (5) & (6) \\
\hline $\begin{array}{l}\text { Occupational Exposure from } \\
\text { Employment in China }\end{array}$ & $\begin{array}{c}-0.00182 * * * \\
(0.0007)\end{array}$ & $\begin{array}{c}-0.00313 * * * \\
(0.0010)\end{array}$ & $\begin{array}{c}-0.00168 * \\
(0.0009)\end{array}$ & $\begin{array}{c}-0.00356 * * \\
(0.0014)\end{array}$ & $\begin{array}{l}-0.0001 \\
(0.0006)\end{array}$ & $\begin{array}{c}0.0004 \\
(0.0010)\end{array}$ \\
\hline Imports & $\begin{array}{c}0.057 \\
(0.038)\end{array}$ & $\begin{array}{c}0.082 \\
(0.053)\end{array}$ & $\begin{array}{c}0.173^{* * *} \\
(0.049)\end{array}$ & $\begin{array}{c}0.255^{* * *} \\
(0.076)\end{array}$ & $\begin{array}{c}-0.127 * * * \\
(0.037)\end{array}$ & $\begin{array}{c}-0.185^{* * *} \\
(0.061)\end{array}$ \\
\hline Exports & $\begin{array}{c}0.019 \\
(0.070)\end{array}$ & $\begin{array}{l}-0.005 \\
(0.099)\end{array}$ & $\begin{array}{l}-0.168 * \\
(0.094)\end{array}$ & $\begin{array}{l}-0.278 * \\
(0.142)\end{array}$ & $\begin{array}{l}0.156 * * \\
(0.070)\end{array}$ & $\begin{array}{l}0.225 * * \\
(0.111)\end{array}$ \\
\hline Computer Use & $\begin{array}{c}-0.0411^{* * *} \\
(0.0059)\end{array}$ & $\begin{array}{c}-0.0338 * * * \\
(0.0083)\end{array}$ & $\begin{array}{c}-0.0615 * * * \\
(0.0075)\end{array}$ & $\begin{array}{c}-0.0549 * * * \\
(0.0098)\end{array}$ & $\begin{array}{c}0.0211^{* * *} \\
(0.0042)\end{array}$ & $\begin{array}{c}0.0223 * * * \\
(0.0059)\end{array}$ \\
\hline Price of Investment Goods & $\begin{array}{l}0.0256^{*} \\
(0.016)\end{array}$ & $\begin{array}{c}0.021 \\
(0.024)\end{array}$ & $\begin{array}{l}0.0837^{* * *} \\
(0.020)\end{array}$ & $\begin{array}{l}0.0956^{* * * *} \\
(0.029)\end{array}$ & $\begin{array}{c}-0.0720 * * * \\
(0.015)\end{array}$ & $\begin{array}{c}-0.101^{* * *} \\
(0.021)\end{array}$ \\
\hline Observations & 89,749 & 34,696 & 89,749 & 34,696 & 89,749 & 34,696 \\
\hline R Squared & 0.32 & 0.31 & 0.32 & 0.33 & 0.17 & 0.17 \\
\hline
\end{tabular}

* significant at $10 \% * *$ significant at $5 \%$.*** significant at $1 \%$.

Source: See Table A1.

Note : Each observation represents a 3-digit occupation X year X 5 year age group cell from ages 15-64. The dependent variable is the listed CPS category (participating in the labor force, employed, or unemployed but participating in the labor force) rate among workers in each cell (weighted by their sample weight), and the independent variable is the lagged log of occupational exposure to Chinese offshore employment. The other controls are as described in Table 2, except that the real value of shipments is used in place of the real price of shipments. The standard errors are clustered by 3-digit occupation and 5-year period, and are robust. 
Table 8: OLS Estimates of Employment Determinants using and Occupational Exposure to Offshoring and Trade among Individuals Observed 2 Periods, 1983-2008

Dependent Variable: Stopped Working (1=yes)

\begin{tabular}{lcccc} 
& \multicolumn{4}{c}{ Offshoring and Trade Measured by } \\
\cline { 2 - 5 } & Occupation-Specific Exposure, All Sectors \\
\cline { 2 - 5 } Variable & $\begin{array}{c}\text { Mll } \\
\text { Occupations }\end{array}$ & $\begin{array}{c}\text { Routine } \\
\text { Intermediate } \\
\text { Routine }\end{array}$ & $\begin{array}{c}\text { Least } \\
\text { Routine }\end{array}$ \\
\hline Lagged log of low income & $0.00643^{*}$ & $0.0151^{* * *}$ & -0.003 & $0.0100^{* *}$ \\
affiliate employment & $(0.004)$ & $(0.004)$ & $(0.005)$ & $(0.005)$ \\
& $-0.00566^{*}$ & $-0.0123^{* * *}$ & -0.011 & $-0.00890^{* *}$ \\
Lagged log of high income & $(0.003)$ & $(0.004)$ & $(0.007)$ & $(0.003)$ \\
affiliate employment & $-0.137^{* *}$ & $-0.255^{* * *}$ & 0.103 & $1.164^{* * *}$ \\
Lagged export share & $(0.063)$ & $(0.084)$ & $(0.100)$ & $(0.366)$ \\
& -0.011 & 0.034 & $-0.120^{*}$ & $-0.775^{* * *}$ \\
Lagged import penetration & $(0.033)$ & $(0.037)$ & $(0.070)$ & $(0.226)$ \\
& $1,377,706$ & 472,215 & 565,291 & 340,200 \\
Number of observations & 0.03 & 0.03 & 0.04 & 0.02 \\
\hline R-squared & &
\end{tabular}

* significant at $10 \% * *$ significant at $5 \%$. ${ }^{* *}$ significant at $1 \%$.

Source: See Table A1.

Note: Robust standard errors are reported in parentheses below the coefficient estimates. The workers are taken from CPS samples from 1983-2008, with their lagged values of the independent variables taken from 1982-2007. The sample is composed of individuals working in the first period and the dependent variable is whether they were working in the second period. The standard errors are clustered by occupation and 5 year period. We also control for the occupation-specific lagged log price of investment, lagged total factor productivity, lagged real price of shipments, and lagged capital to labor ratio. Individualspecific controls include a worker's gender, age, race, experience, whether in a union, and fixed effects for industry (3-digit), occupation (2-digit), year, education and state. Controls for computer use rates are imputed by the worker's occupation using the CPS computer supplement and are included in all specifications. 


\section{Table 9: OLS Estimates of Employment Determinants using and Occupational Exposure to Offshoring to China and Trade among Individuals Observed 2 Periods, 1983-2008}

Dependent Variable: Stopped Working (1=yes)

\begin{tabular}{|c|c|c|c|c|}
\hline \multirow[b]{2}{*}{ Variable } & \multicolumn{4}{|c|}{$\begin{array}{c}\text { Offshoring and Trade Measured by } \\
\text { Occupation-Specific Exposure, All Sectors }\end{array}$} \\
\hline & $\begin{array}{c}\text { All } \\
\text { Occupations }\end{array}$ & $\begin{array}{c}\text { Most } \\
\text { Routine }\end{array}$ & $\begin{array}{l}\text { Intermediate } \\
\text { Routine }\end{array}$ & $\begin{array}{c}\text { Least } \\
\text { Routine }\end{array}$ \\
\hline $\begin{array}{l}\text { Lagged log of Chinese } \\
\text { affiliate employment }\end{array}$ & $\begin{array}{l}0.00217 * * * \\
\quad(0.001)\end{array}$ & $\begin{array}{c}0.00296 * * * \\
(0.001)\end{array}$ & $\begin{array}{c}0.002 \\
(0.001)\end{array}$ & $\begin{array}{c}0.001 \\
(0.002)\end{array}$ \\
\hline $\begin{array}{l}\text { Lagged log of high income } \\
\text { affiliate employment }\end{array}$ & $\begin{array}{l}-0.001 \\
(0.001)\end{array}$ & $\begin{array}{c}0.000 \\
(0.001)\end{array}$ & $\begin{array}{c}-0.0133^{* *} \\
(0.005)\end{array}$ & $\begin{array}{l}-0.001 \\
(0.002)\end{array}$ \\
\hline Lagged export share & $\begin{array}{c}-0.161^{* * *} \\
(0.061)\end{array}$ & $\begin{array}{c}-0.295^{* * *} \\
(0.086)\end{array}$ & $\begin{array}{c}0.138 \\
(0.094)\end{array}$ & $\begin{array}{c}1.266^{* * *} \\
(0.384)\end{array}$ \\
\hline Lagged import penetration & $\begin{array}{l}-0.016 \\
(0.032)\end{array}$ & $\begin{array}{c}0.042 \\
(0.039)\end{array}$ & $\begin{array}{c}-0.180 * * * \\
(0.069)\end{array}$ & $\begin{array}{c}-0.799 * * * \\
(0.234)\end{array}$ \\
\hline $\begin{array}{l}\text { Number of observations } \\
\text { R-squared }\end{array}$ & $\begin{array}{c}1,377,706 \\
0.03\end{array}$ & $\begin{array}{c}472,215 \\
0.03\end{array}$ & $\begin{array}{c}565,291 \\
0.04\end{array}$ & $\begin{array}{c}340,200 \\
0.02\end{array}$ \\
\hline
\end{tabular}

* significant at $10 \% * *$ significant at $5 \%$. *** significant at $1 \%$.

Source: See Table A1.

Note : Robust standard errors are reported in parentheses below the coefficient estimates. The workers are taken from CPS samples from 1983-2008, with their lagged values of the independent variables taken from 1982-2007. The sample is composed of individuals working in the first period and the dependent variable is whether they were working in the second period. The standard errors are clustered by occupation and 5 year period. We also control for the occupation-specific lagged log price of investment, lagged total factor productivity, lagged real price of shipments, and lagged capital to labor ratio. Individualspecific controls include a worker's gender, age, race, experience, whether in a union, and fixed effects for industry (3-digit), occupation (2-digit), year, education and state. Controls for computer use rates are imputed by the worker's occupation using the CPS computer supplement and are included in all specifications. 


\section{Figure 1}

Trends in Employment and Wages in the Manufacturing and Service Sectors
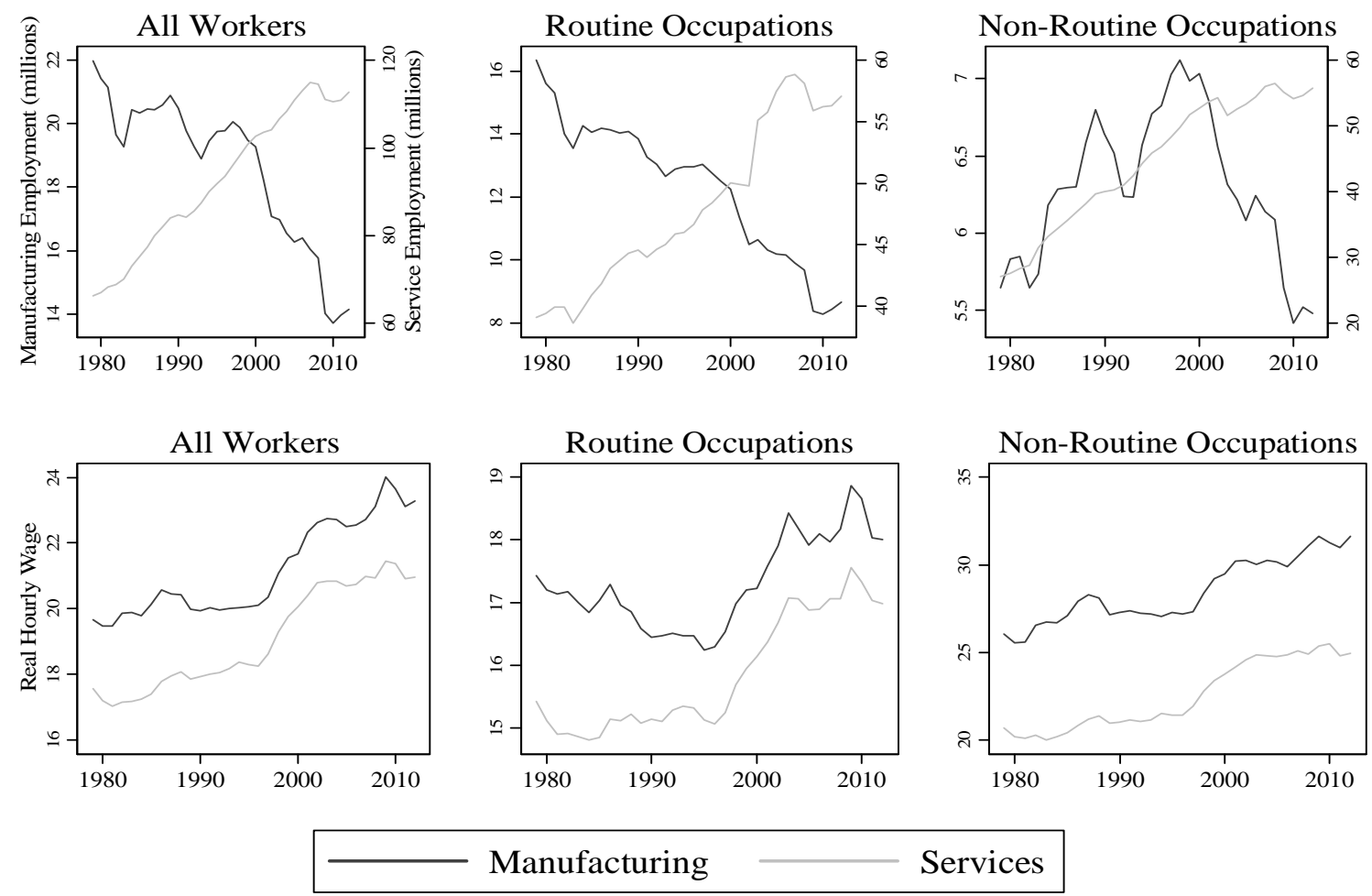

Notes : Employment and wage calculations are based on the Current Population Survey Merged Outgoing Rotation Groups (MORG). Sample includes all part-time and full-time workers. Wages are in 2012 dollars. Definition of routine workers is based on occupational task content. Details are available in the data appendix. 


\section{Figure 2}

Trends in Domestic and Affiliate Employment among Multinational Firms

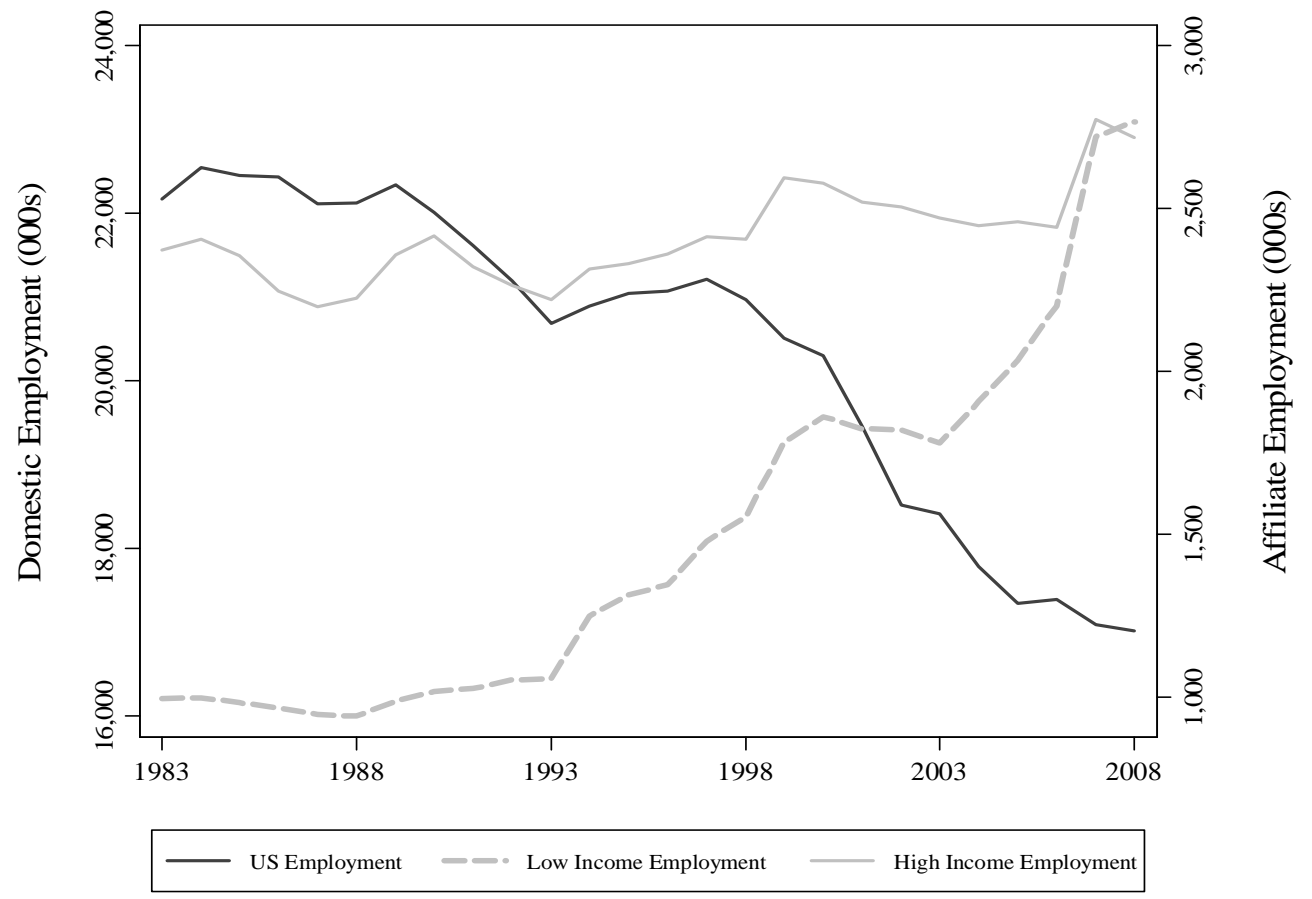

Source: Bureau of Economic Analysis

Notes : Author's calculations based on the most comprehensive available data and is based on firm-level surveys on US direct investment abroad, collected each year by the Bureau of Economic Analysis (BEA) of the US Department of Commerce. Using these data, we compute number of employees hired abroad by country and year, and then aggregate employment by Low (High) Income country according to World Bank income classifications. 


\section{Figure 3}

Trends in Manufacturing Affiliate Employment in Low Income Countries

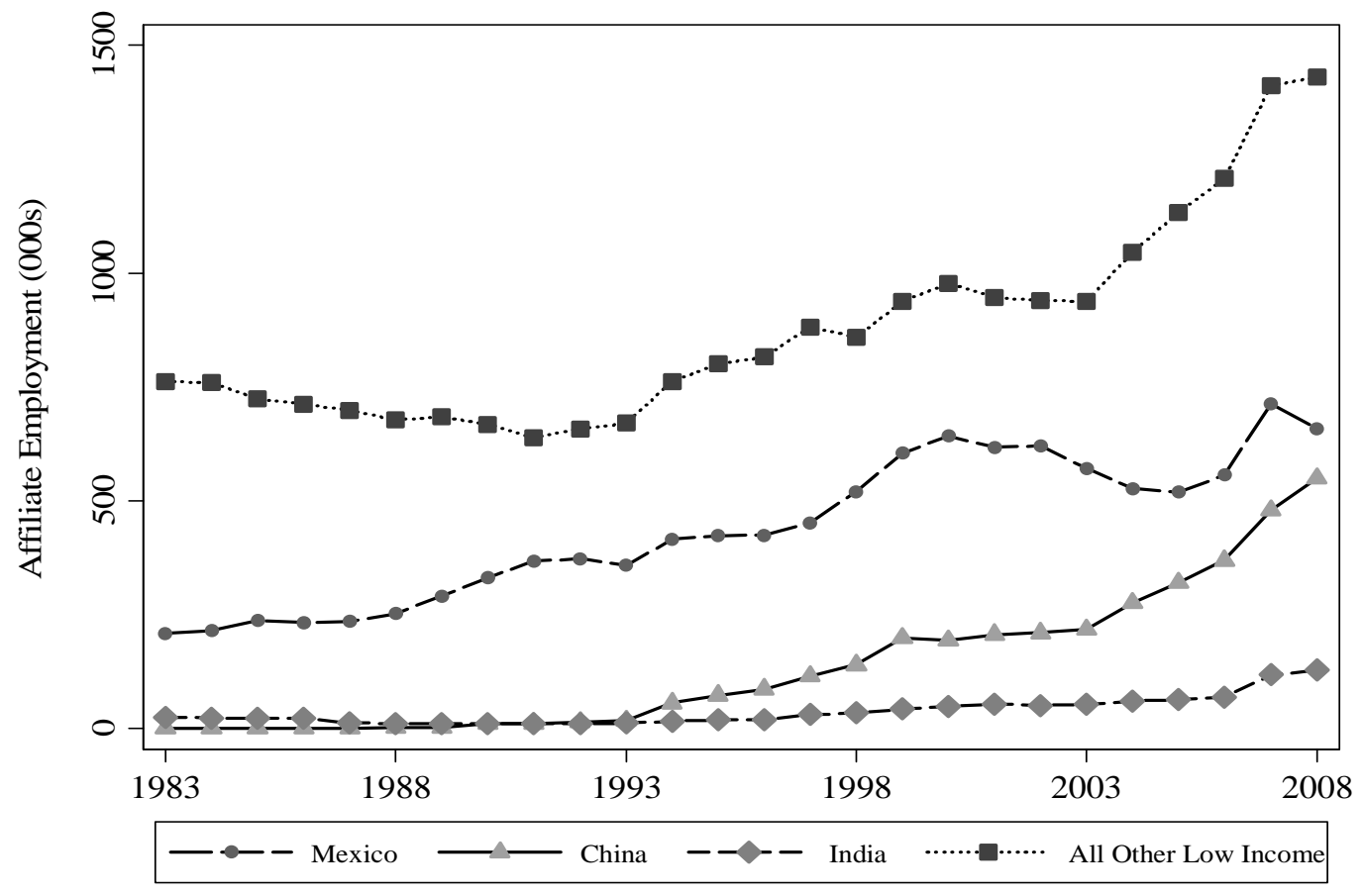

Source: Bureau of Economic Analysis

Notes : The "alll others" category includes all employment in low income countries other than Mexico, China, and India. 
Table A1: Sample Averages for Current Population Survey Merged Outgoing Rotation Group Workers, 1983-2008

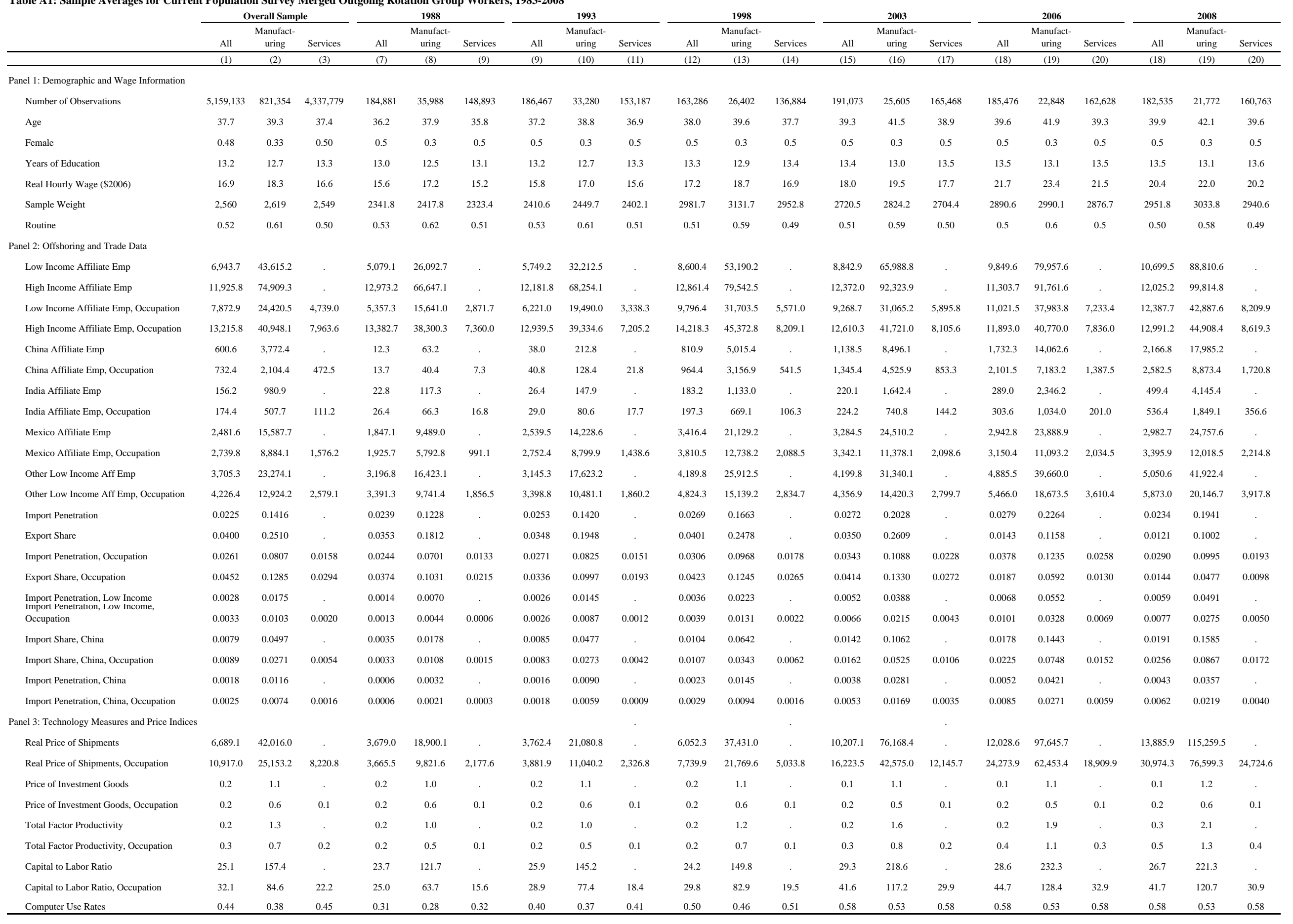

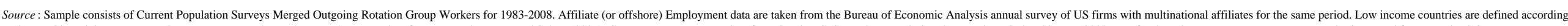

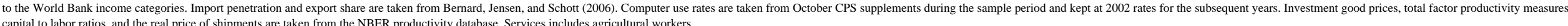

